\title{
Pluripotency of mesenchymal cells derived from synovial fluid in patients with temporomandibular joint disorder.
}

\section{$\operatorname{AUTHOR}(\mathrm{S}):$}

Koyama, Noriaki; Okubo, Yasunori; Nakao, Kazumasa; Osawa, Kenji; Fujimura, Kazuma; Bessho, Kazuhisa

\section{CITATION:}

Koyama, Noriaki ... [et al]. Pluripotency of mesenchymal cells derived from synovial fluid in patients with temporomandibular joint disorder.. Life sciences 2011, 89(19-20): 741-747

\section{ISSUE DATE:}

2011-11-07

URL:

http://hdl.handle.net/2433/149606

\section{RIGHT:}

(C) 2011 Published by Elsevier Inc.; この論文は出版社版でありません。 引用の際には出版社版をご確認ご利用ください。; This is not the published version. Please cite only the published version. 
Pluripotency of mesenchymal cells derived from synovial fluid in patients with temporomandibular joint disorder

Noriaki Koyama, D.D.S., Yasunori Okubo, D.D.S., Ph.D., Kazumasa Nakao, D.D.S., Kenji Osawa, D.D.S., Kazuma Fujimura, D.D.S., Ph.D., Kazuhisa Bessho, D.D.S., Ph.D.

Department of Oral and Maxillofacial Surgery, Graduate School of Medicine, Kyoto University, Kyoto 606-8507, Japan.

Correspondence to:

Noriaki Koyama, D.D.S.

Department of Oral and Maxillofacial Surgery, Graduate School of Medicine, Kyoto University, 54 Shogoin Kawahara-cho, Sakyo-ku, Kyoto 606-8507, Japan.

Phone: +81-75-751-3401, FAX: +81-75-761-9732

E-mail: nori1121@kuhp.kyoto-u.ac.jp 


\begin{abstract}
Aims: Mesenchymal stem cells are an interesting source of material for regenerative medicine. The present study aimed at characterizing the phenotype and differentiation potential of adherent synovial fluid-derived cells from temporomandibular joint (TMJ) disorder patients.
\end{abstract}

Main methods: Synovial fluid collection takes place during TMJ cavity irrigation arthrocentesis under local anesthesia. The synovial fluid-derived adherent cells were fibroblast-like and spindle-shaped. Ex vivo-expanded synovial fluid-derived cells were shown to express STRO-1 and CD146, previously found to be present in bone marrow mesenchymal stem cells. Further, they were identified as being capable of differentiating into a variety of cell types including osteoblasts, chondrocytes, adipocytes, and neurons.

Key findings: The present study demonstrates that human pluripotent cells can be isolated from synovial fluid. These synovial fluid-derived cells cannot only be derived from a very accessible resource, but are also capable of providing sufficient cells for potential clinical applications.

Significance: These cells may play a role in the regenerative response during arthritic diseases and are promising candidates for developing novel cell-based therapeutic approaches for postnatal skeletal tissue repair.

\title{
Keywords
}

synovial fluid; mesenchymal stem cells; chondrogenesis; temporomandibular joint disorder 


\section{Introduction}

Articular cartilage has a limited capacity for healing after injury. Mesenchymal stem cells (MSCs) are interesting sources of material for regenerative medicine. In vitro chondrogenesis of bone marrow-derived MSCs was first reported by Johnstone et al (Johnstone et al. 1998). Bone marrow-derived MSCs have been extensively investigated; however, there are increasing reports that MSCs are present in various tissues, one of which is synovial fluid (Jones et al. 2004). Mesenchymal pluripotent cells can be isolated from synovial fluid, but the number of cells that can be harvested may be limited. Synovium-derived cells have been found to exhibit a high potential for both proliferation and differentiation (Sakaguchi et al. 2005; DeBari et al. 2001; Koga et al. 2007; Nishimura et al. 1999; Miyamoto et al. 2007). Synovial tissues are straightforward to harvest and may be collected from any joint without damaging the articular cartilage.

Normal synovial fluid is a dialysate of blood plasma with the addition of components synthesized by synovial tissue and catabolic products from the surrounding tissues, for example, proteoglycan and collagen breakdown products (Swann et al. 1978). Synovial fluid nourishes articular cartilage, contains growth factors, and, 
dependent on the status of the joint, pro- and anti-inflammatory cytokines (Fernandes et al. 2002; Neidel et al. 1996; Okazaki et al. 2001). Relatively little is known about the role of synovial fluid in cartilage turnover, particularly during cartilage regeneration after injury. Autologous synovial fluid obtained from healthy equine joints has been demonstrated to support the chondrogenic differentiation of equine mesenchymal stem cells (Hegewald et al. 2004). However, various studies suggest that joint homeostasis is disturbed in traumatized joints, which was found to adversely affect chondrogenesis (Rodrigo et al. 1995; Saris et al. 2003).

In this study, we isolated a distinctive population of pluripotent cells from synovial fluid in patients with temporomandibular joint (TMJ) disorder. The significance of this study is that it provides evidence that a small amount of synovial fluid-derived pluripotent cells are similar to previously validated cell lineages, containing stem cells that may offer a unique stem-cell resource for potential clinical applications.

\section{Materials and Methods}

\section{Synovial fluid collection from temporomandibular joint.}

Synovial fluid samples were collected from patients with TMJ disorder who was ineffectual in conservative treatment, either during the arthrocentesis or arthroscopic 
surgery of the TMJ under approved guidelines set by Kyoto University Graduate School and the Faculty of Medicine Ethics Committee (C-172). The joint space was expanded with 1.5-2.0 $\mathrm{ml}$ normal saline before the introduction of the arthroscope, and this fluid was then reaspirated.

Isolation and culture of human synovial fluid-derived cells.

Within $6 \mathrm{~h}$ after aspiration, synovial fluid was plated in $60-\mathrm{mm}$ culture dishes in complete culture medium: Advanced DMEM $\left(\mathrm{GIBCO}^{\circledR}\right.$ Invitrogen, Carlsbad, CA, USA) containing 5\% fetal bovine serum (FBS; CELLect ${ }^{\mathrm{TM}}$ GOLD, MP Biomedicals, Inc., Solon, OH, USA), 2 mM L-glutamine $\left(\mathrm{GIBCO}^{\circledR}\right), 100 \mathrm{U} / \mathrm{ml}$ penicillin, and 100 $\mu \mathrm{g} / \mathrm{ml}$ streptomycin (Pen Strep, GIBCO ${ }^{\circledR}$ ), and then incubated at $37^{\circ} \mathrm{C}$ in $5 \% \mathrm{CO}_{2}$. After 3-4 days, the medium was removed to take away non-adherent cells and replaced with fresh medium. The cells were expanded in a monolayer for 3-5 passages.

\section{Fluorescence-activated cell sorting.}

Flow cytometry was performed with a FACScan (BD Biosciences, Bedford, MA,

USA). The following antibodies were used: anti-human STRO-1 (R\&D Systems, Inc.,

Minneapolis, MN, USA), phycoerythrin (PE)-conjugated anti-human CD34 (BD

Biosciences), fluorescein isothiocyanate (FITC)-conjugated anti-human CD45 (BD 
Biosciences), PE-conjugated anti-human CD146 (BD Biosciences), and mouse control IgM (Southern Biotech, Birmingham, AL, USA). FITC-conjugated goat anti-human and anti-mouse $\operatorname{IgM}$ were from Southern Biotech. The cells were collected from culture and incubated with STRO-1, CD146, CD45, and CD34 antibodies or negative control antibodies for $1 \mathrm{~h}$ at $4^{\circ} \mathrm{C}$. The fluorescence-activated cell-sorting analysis was conducted as described previously (Gronthos et al. 2002).

\section{Morphology and immunocytochemistry.}

The cells were plated in chamber slides and cultured for 7 days. The cells were washed with phosphate-buffered saline (PBS), fixed in 3\% paraformaldehyde (PFA) in PBS for 5 min at room temperature, and washed with PBS containing $0.1 \%$ triton X-100. The cells were blocked in PBS (+) containing $2 \%$ bovine serum albumin for $30 \mathrm{~min}$ at room temperature. The cells were then incubated overnight at $4{ }^{\circ} \mathrm{C}$ with primary antibodies diluted in blocking solution. The following primary antibodies were used: anti-human STRO-1 (1:100; MAB1038, R\&D Systems, Inc., Minneapolis, MN, USA), CD34 (1:200; MS-363-P0, Lab Vision Corporation, Fremont, CA, USA), CD45 (1:200; MS-413-P0, Lab Vision Corporation), Neuron-specific nuclear protein (NeuN) (1:100; MAB377, Chemicon, Temecula, CA, USA), and Nestin (1:100; MAB1259, R\&D 
Systems, Inc.). The cells were washed with PBS and then incubated with secondary antibodies (1:200; 1020-02, FITC conjugated Goat Anti-Mouse IgM, SouthernBiotech), (1:200; AP127F, Goat Anti-Mouse IgG, Fc, FITC conjugate, Chemicon), and (1:100; 03-18-06, Rhodamine-Labeled Goat Anti-Mouse IgG (H+L), KPL, Gaithersburg, MD, USA) in blocking solution at room temperature and shielded from the light for $2 \mathrm{~h}$. The cells were counterstained with DAPI (1:1,000; 71-03-00, KPL). Finally, the slides were washed and cover-slipped with VECTASHIELD ${ }^{\circledR}$ Mounting Medium (Vector Laboratories, Inc., Burlingame, CA, USA).

\section{Chondrocyte differentiation.}

For chondrocyte differentiation, a micromass culture system was used as previously reported (Johnstone et al. 1998; Koyama et al. 2009). The cells were suspended in chondrogenic inductive medium that consisted of DMEM/F-12 (GIBCO $\left.{ }^{\circledR}\right)$ containing 10\% FBS, 1x ITS $+{ }^{\mathrm{TM}}$ Premix (BD Biosciences; $6.25 \mu \mathrm{g} / \mathrm{ml}$ bovine insulin, $6.25 \mu \mathrm{g} / \mathrm{ml}$ transferrin, $6.25 \mathrm{ng} / \mathrm{ml}$ selenious acid, $1.25 \mathrm{mg} / \mathrm{ml}$ bovine serum albumin, and $5.35 \mu \mathrm{g} / \mathrm{ml}$ linoleic acid), $50 \mu \mathrm{g} / \mathrm{ml} \mathrm{L-ascorbic} \mathrm{acid} \mathrm{2-phosphate,} 100 \mu \mathrm{g} / \mathrm{ml}$ sodium pyruvate (Wako Pure Chemical Industries, Ltd., Osaka, Japan), 100 nM dexamethasone, $100 \mathrm{U} / \mathrm{ml}$ penicillin, and $100 \mu \mathrm{g} / \mathrm{ml}$ streptomycin at a concentration of $1 \times 10^{7}$ cells $/ \mathrm{ml}$, 
and then $20 \mu 1$ of cells was placed in 12 -well plates. The cells were allowed to adhere for $6 \mathrm{~h}$ at $37{ }^{\circ} \mathrm{C}$ in $5 \% \mathrm{CO}_{2}$, and then $1 \mathrm{ml}$ of chondrogenic inductive medium with 100 ng/ml rhBMP-2 or complete culture medium as a control group was added. The medium was renewed every 3 days for 14 days.

\section{Osteoblast differentiation.}

The cells were placed in 12-well plates, and incubated in complete culture medium at $37^{\circ} \mathrm{C}$ in $5 \% \mathrm{CO}_{2}$. At confluence, the medium was then switched to osteogenic induction medium that consisted of $\alpha \mathrm{MEM}\left(\mathrm{GIBCO}^{\circledR}\right)$ containing $15 \% \mathrm{FBS}, 2 \mathrm{mM}$ L-glutamine, $100 \mu \mathrm{M}$ L-ascorbic acid 2-phosphate (Wako), $10 \mathrm{mM}$ sodium $\beta$-glycerophosphate (Wako), $10 \mathrm{nM}$ dexamethasone (Sigma-Aldrich, Milwaukee, WI, USA), $100 \mathrm{U} / \mathrm{ml}$ penicillin, and $100 \mu \mathrm{g} / \mathrm{ml}$ streptomycin. The control group was also incubated in complete culture medium. The medium was renewed every 3 days for 28 days.

\section{Adipocyte differentiation.}

The cells were plated in 12-well plates and cultured in complete culture medium.

At confluence, the medium was then switched to adipogenic induction medium that consisted of $\alpha \mathrm{MEM}$ containing 20\% FBS, $2 \mathrm{mM}$ L-glutamine, $60 \mu \mathrm{M}$ indomethacin 
(Sigma-Aldrich), $100 \mu \mathrm{M}$ L-ascorbic acid 2-phosphate, $0.5 \mathrm{mM}$ isobutyl methylxanthin (Sigma-Aldrich), $0.5 \mu \mathrm{M}$ hydrocortisone (Sigma-Aldrich), $10 \mu \mathrm{g} / \mathrm{ml}$ insulin (MP Biomedicals, Inc.), $100 \mathrm{U} / \mathrm{ml}$ penicillin, and $100 \mu \mathrm{g} / \mathrm{ml}$ streptomycin to induce adipocytes to differentiate for 3 days. Then, the medium was switched to maintenance medium that consisted of $\alpha$ MEM containing 20\% FBS, $2 \mathrm{mM}$ L-glutamine, $100 \mu \mathrm{M}$ L-ascorbic acid 2-phosphate, $10 \mu \mathrm{g} / \mathrm{ml}$ insulin (MP Biomedicals, Inc.), $100 \mathrm{U} / \mathrm{ml}$ penicillin, and $100 \mu \mathrm{g} / \mathrm{ml}$ streptomycin for 3 days. After being stimulated for 3 cycles, the cells were cultured in maintenance medium for 3 days.

\section{Neuron differentiation.}

The cells were plated in chamber slides and maintained in complete culture medium at $37^{\circ} \mathrm{C}$ in $5 \% \mathrm{CO}_{2}$. After achieving confluence, the medium was switched to a neuronal induction medium that consisted of $\mathrm{Neurobasal}^{\mathrm{TM}}-\mathrm{A}$ media $\left(\mathrm{GIBCO}^{\circledR}\right)$ containing 1x B-27 Supplement $\left(\mathrm{GIBCO}^{\circledR}\right.$ ), $20 \mathrm{ng} / \mathrm{ml} \mathrm{rhEGF}$ (Wako), 40 ng/ml bFGF (R\&D Systems, Inc.), $100 \mathrm{U} / \mathrm{ml}$ penicillin, and $100 \mu \mathrm{g} / \mathrm{ml}$ streptomycin to differentiate for 14 days. The medium was renewed every 3 days.

\section{Alkaline phosphatase (ALP) activity.}

For osteogenic differentiation on day 28 , and for chondrogenic differentiation on 
day 14 , the growth medium was removed and then the cells were washed with PBS and lysed in homogenized buffer (pH 7.4) that consisted of $150 \mathrm{mM} \mathrm{NaCl}, 3 \mathrm{mM} \mathrm{NaHCO}$, $0.1 \%$ Triton X-100, and distilled water. ALP activity of the supernatant obtained was determined employing the p-Nitrophenylphosphate method using Lab Assay ${ }^{\mathrm{TM}}$ ALP (Wako). The protein concentration was determined using a Micro $\mathrm{BCA}^{\mathrm{TM}}$ Protein Assay Reagent Kit (Pierce, Thermo Fisher Scientific, Rockford, IL, USA).

\section{Oil red O staining.}

The adipogenic cultures were fixed in 4\% PFA for $10 \mathrm{~min}$, rinsed twice with PBS, stained with a fresh $0.3 \%$ oil red $\mathrm{O}$ solution for $10 \mathrm{~min}$, and washed with distilled water.

To determine the specificity of the responding cells for adipogenesis, we examined the oil red O staining of lipid droplets.

\section{Toluidine blue staining.}

The micromass cultures were fixed in 4\% PFA for $10 \mathrm{~min}$, and then embedded in paraffin, cut into $5-\mu \mathrm{m}$ sections, and stained with toluidine blue.

\section{Von Kossa staining.}

At 28 days following osteogenic induction, the culture plates were rinsed with PBS and fixed in 4\% PFA for $10 \mathrm{~min}$, and then rinsed with distilled water. Five 
percent silver nitrate solution was added, and the plate was exposed to UV light for 3 min, after which it was washed well with distilled water. Five percent sodium thiosulfate was added for $5 \mathrm{~min}$, and the plates were then rinsed in running tap water for 5 min.

\section{Real-time reverse transcription (RT)-PCR.}

Total RNA was isolated from cultures using the RNeasy ${ }^{\circledR}$ Mini Kit (Qiagen, Valencia, CA, USA). To ensure the complete removal of DNA, we included a 15-min DNase I (Qiagen) treatment prior to the washing step of the isolation. First-strand cDNA synthesis was performed using $\operatorname{TaqMan}^{\circledR}$ Reverse Transcription Reagents (Applied BioSystems, Foster City, CA, USA) with random hexamers, according to the manufacturer's protocol. Reverse transcription (RT) involved a 30-min incubation at $48^{\circ} \mathrm{C}$, followed by a 5 -min incubation at $95^{\circ} \mathrm{C}$ to inactivate the reverse transcriptase. Real-time RT-PCR was performed in a StepOne ${ }^{\mathrm{TM}}$ real-time PCR System (Applied BioSystems). cDNA was mixed with TaqMan ${ }^{\circledR}$ Universal PCR Master Mix (Applied BioSystems) and TaqMan ${ }^{\circledR}$ Gene Expression Assay (Applied BioSystems) primer: 18S ribosomal RNA (18S) (Assay ID Hs99999901_s1), osteocalcin (BGLAP) (Assay ID Hs00609451_g1), type II collagen (Assay ID Hs00264051_m1), and type X collagen 
(Assay ID Hs00166657_m1). 18S primers were used to provide a control amount of RNA in each sample, and reactions for each sample were performed in triplicate. After an initial denaturation step $\left(95{ }^{\circ} \mathrm{C}\right.$ for $10 \mathrm{~min}$ ), amplification was performed for 45 cycles $\left(95^{\circ} \mathrm{C}\right.$ for $15 \mathrm{sec}, 60{ }^{\circ} \mathrm{C}$ for $\left.60 \mathrm{sec}\right)$.

\section{RT-PCR.}

First-strand cDNA $(2 \mu \mathrm{l})$ was diluted in a $20-\mu \mathrm{l}$ reaction mixture containing GeneAmp $^{\circledR}$ Fast PCR Master Mix (2x) (Applied BioSystems) and $500 \mathrm{nM}$ of each human-specific primer set: peroxisome proliferator-activated receptor- $\gamma 2$ (PPAR $\gamma 2$ ) sense (5'-GCTCTGCAGGAGATCACAGA-3') and asense (5'-GGGCTCCATAAAGTCACCAA-3') (GenBank accession no. $\underline{\text { NM005037); }}$ lipoprotein lipase (LPL) sense (5'-GTCCGTGGCTACCTGTCATT-3') and antisense (5'-TGTCCCACCAGTTTGGTGTA-3') (GenBank accession no. NM000237); and glyceraldehyde-3-phosphate dehydrogenase $\quad$ (GAPDH) sense (5'-AGCCGCATCTTCTTTTGCGTC-3') antisense (5'-TCATATTTGGCAGGTTTTTCT-3') (GenBank accession no. NM002046). The reactions were incubated in a GeneAmp ${ }^{\circledR}$ PCR system 9700 (Applied BioSystems) at $94{ }^{\circ} \mathrm{C}$ for $2 \mathrm{~min}$ for one cycle and then $94{ }^{\circ} \mathrm{C}$ for $45 \mathrm{sec}, 64{ }^{\circ} \mathrm{C}$ for $45 \mathrm{sec}, 72{ }^{\circ} \mathrm{C}$ for 60 
sec, for 35 cycles, with a final 7-min extension at $72{ }^{\circ} \mathrm{C}$. After amplification, $10 \mu 1$ of each reaction was analyzed by $2 \%$ agarose gel electrophoresis, and visualized by ethidium bromide staining (Gronthos et al. 2002; Miura et al. 2003).

\section{Statistical analysis.}

All experiments were repeated a minimum of three times. Data are presented as means \pm standard deviations. Significant differences were evaluated using Student's t-tests where appropriate. P-values of less than 0.05 were considered significant.

\section{Results}

Synovial fluid-derived cells. Synovial fluid samples were plated and cultured for 14-21 days with the complete culture medium. The synovial fluid-derived adherent cells were mostly cells that had retained their fibroblastic spindle shape (Figure 1A).

Fluorescence-activated cell sorting analysis. CD34 and CD45 were primarily expressed on the cells of hematopoietic origin. We found that synovial fluid-derived cells did not express CD34 and CD45. Ex vivo-expanded synovial fluid-derived cells were found to express STRO-1 and CD146, two early mesenchymal stem cell markers previously found to be present in bone marrow mesenchymal stem cells (data not shown). 
Morphology and immunocytochemistry. We found that synovial fluid-derived cells did not express CD34 and CD45 (Figure $1 \mathrm{~B}$ and C), and ex vivo-expanded synovial fluid-derived cells were found to express STRO-1 by immunocytochemistry (Figure 1D).

Chondrogenic differentiation. ALP activity on day 14 after treatment was higher than in the control group (Figure 2A). In micromass cultures treated with BMP-2, many cartilage nodules appeared and were positively stained with toluidine blue, and some of the cells in the nodules differentiated into hypertrophic chondrocytes (Figure 2B). The efficiency of chondrogenesis was also greater than in the control group. BMP-2 treatment caused the cultured cells to express higher levels of chondrogenic markers, type II and type X collagen, as determined by real-time RT-PCR (Figure $2 \mathrm{C}$ and D).

Osteoblast differentiation. To evaluate the osteogenic potential of the synovial fluid-derived cells, the cells were cultured in osteogenic induction medium. After 28 days, we found that the calcium deposits were stained with von Kossa in cultured cells (Figure 3A). In addition, the ALP activity on day 28 after treatment with the osteogenic induction medium was markedly increased compared to the control group 
(Figure 3B). The osteogenic induction medium showed more marked induction than the complete culture medium, and it increased the expression of osteocalcin (bone Gla protein: BGLAP) as determined by real-time RT-PCR (Figure 3C).

Adipogenic differentiation. After 21 days of culture with an adipogenic inductive medium, the cells developed into oil red O-positive lipid-laden fat cells (Figure 4A). This development was correlated with an upregulation in the expression of 2 adipocyte-specific transcripts, PPAR $\gamma 2$ and LPL, as detected by RT-PCR (Figure 4B).

Neurogenic differentiation. Following 14 days of induction, the cells exposed to neuronal induction medium acquired a bipolar and stellate morphology consistent with that of sensory and motor neurons (Figure $4 \mathrm{C}$ and D). The protein expression pattern of early (Nestin) and late (NeuN) neuron-associated markers expressed in neuron-inducing conditions was determined by immunocytochemical analysis (Lendahl et al. 1990; Mullen et al. 1992; Sarnat et al. 1998). The cells showed positive staining for these neuronal markers (Figure $4 \mathrm{E}$ and F).

\section{Discussion}

In this study, we examined the potential of human synovial fluid-derived pluripotent cells from patients with TMJ disorder to undergo chondrogenic, osteogenic, 
adipogenic, and neurogenic differentiation in vitro. We investigated phenotypes according to the morphology, protein assays, and the expression of specific markers employing RT-PCR and real-time RT-PCR.

Intra-articular bleeding can trigger an increase in synovial fluid mesenchymal cells. When disc injury causes rupture and bleeding, the synovial fluid contains blood for several days. Vessel injury and bleeding promote the expression of cytokines, chemokines, and, consequently, recruit MSCs. Generally, synovial fluids within a few days after intra-articular ligament injury are bloody, and then become transparent thereafter. In a previous study, they aspirated synovial fluids in the knee joints on average 37 weeks after ligament injuries, and most synovial fluid appeared transparent, indicating that intra-articlar bleeding can trigger an increase of synovial fluid MSCs in the early phase (Morito et al. 2008).

Inflammation may affect synovial fluid MSCs. Jones et al. examined synovial fluid MSCs derived from a swollen knee joint, and described their possible role in the pathophysiology of arthritis (Jones et al. 2004). The amount of synovial fluid from pre-operative patients was $\sim 1 \mathrm{ml}$ or less in most cases, and synovial fluid appeared not to be cloudy, indicating a low number of inflammatory cells. Inflammation may 
increase the number of MSCs in the early phase but would not maintain the increase of

MSCs (Morito et al. 2008).

It was recently reported by Mochizuki et al. that fibrous synovium, harvested from the inner side of the lateral joint capsule, and adipose synovium, harvested from the infrapatellar fat pad, exhibited similar growth and differentiation potentials in young patients with anterior cruciate ligament injury and in elderly patients with osteoarthritis (OA) (Mochizuki et al. 2006). These findings suggest that adherent colony-forming cells derived from the synovium have a similar proliferation capacity and multipotentiality, independent of the location in the knee. In another study, they also demonstrated that the capacity for proliferation and potential for chondrogenesis of synovial MSCs were similar among the different harvest sites in the OA synovium (Nagase et al. 2008). These pluripotent cells can be isolated and expanded ex vivo, thereby providing a unique and accessible population of pluripotent cells from an unexpected tissue resource. Numbers of synovial fluid mesenchymal cells increased and were possibly derived from dislodged synovial fragments. This is particularly noteworthy since synovial cells have been proposed to contribute to spontaneous cartilage repair (Hunziker et al. 1996). It is now well-accepted that tissue destruction 
in OA is closely associated with attempted repair processes (Luyten et al. 2006), which may be mediated, at least in part, by the synovial fluid microenvironment (Jones et al. 2008).

TMJ disorders are common in adults; as many as one third of adults report having one or more symptoms, which include jaw or neck pain, headache, and clicking or grating within the joint (Buescher 2007). Mesenchymal stem cells were found in knee synovial fluid with OA patients (Jones et al. 2008). In our study, mesenchymal cells were derived from synovial fluid in patients with TMJ disorder.

The chondrogenic differentiation of mesenchymal progenitors can be induced by the stimulation of cells with BMP (Sekiya et al. 2005; Schmitt et al. 2003; Barry et al. 2001). In addition, synovial fluid itself and its major component hyaluronan have been shown to induce chondrogenesis in equine bone marrow-derived mesenchymal stem cells (Hegewald et al. 2004).

Mesenchymal cells we isolated from the synovial fluid of a person with TMJ disorder showed proliferation and ALP activity rates similar to those of human bone marrow-derived MSCs under the same conditions.

There was no difference in the differentiative potential when synovial fluid-derived cells 
were compared with bone marrow-derived MSCs.

The ease of availability of mesenchymal pluripotent cells in human synovial fluid allows the realization of important therapeutic options in regenerative medicine. TMJ cavity irrigation and pumping are usually conducted under local anesthesia. The TMJ cavity is very small. Therefore, collection is limited to a very small amount of synovial fluid. However, our isolated mesenchymal pluripotent cells derived from synovial fluid were able to enhance in vitro expansion and could be collected easily compared to bone marrow-derived MSCs. These cells can be subsequently used for the regeneration of skeletal tissues.

The results suggest the possibility that synovial fluid-derived cells can be applied to treat serious TMJ disorders with OA and internal derangement. Moreover, these cells can be differentiated into not only osteoblasts and chondrocytes, but also neurons and adipocytes.

The collection of synovial cells is a by-product of the operation under general anesthesia. In other words, the operation is necessary in order to harvest the synovium. However, the synovial fluid can be harvested by syringe aspiration during the operation. The synovial fluid-derived cells are not only derived from a very accessible resource, 
but are also capable of potentially providing sufficient cells for clinical application.

This suggests the utility as a potential cell source for tissue engineering applications.

\section{Conclusion}

We demonstrated that synovial fluid included mesenchymal pluripotent cells from

patients with TMJ disorder. We confirmed that the human synovial fluid is a good source of progenitor cells with the capacity to differentiate towards several cell lineages.

These findings provide a platform for the exploration of the potential role of synovial fluid-derived mesenchymal pluripotent cells in TMJ homeostasis, and for the investigation of their therapeutic potential in novel regeneration strategies. 


\section{References}

Barry F, Boynton RE, Liu B, Murphy JM. Chondrogenic differentiation of mesenchymal stem cells from bone marrow: differentiation-dependent gene expression of matrix components. Exp Cell Res 2001;268(2):189-200.

Buescher JJ. Temporomandibular joint disorders. Am Fam Physician 2007;76(10):1477-82.

De Bari C, Dell'Accio F, Tylzanowski P, Luyten FP. Multipotent mesenchymal stem cells from adult human synovial membrane. Arthritis Rheum 2001;44(8):1928-42.

Fernandes JC, Martel-Pelletier J, Pelletier JP. The role of cytokines in osteoarthritis pathophysiology. Biorheology 2002;39(1):237-46.

Gronthos S, Brahim J, Li W, Fisher LW, Cherman N, Boyde A, DenBesten P, Robey PG, Shi S. Stem cell properties of human dental pulp stem cells. J Dent Res 2002;81(8):531-5.

Hegewald AA, Ringe J, Bartel J, Krüger I, Notter M, Barnewitz D, Kaps C, Sittinger M. Hyaluronic acid and autologous synovial fluid induce chondrogenic differentiation of equine mesenchymal stem cells: a preliminary study. Tissue Cell 2004;36(6):431-8.

Hunziker, EB, Rosenberg, LC. Repair of partial-thickness defects in articular cartilage: 
cell recruitment from the synovial membrane. J Bone Joint Surg Am 1996;78(5):721-33.

Johnstone B, Hering TM, Caplan AI, Goldberg VM, Yoo JU. In vitro chondrogenesis of bone marrow-derived mesenchymal progenitor cells. Exp Cell Res 1998;238(1):265-72.

Jones EA, English A, Henshaw K, Kinsey SE, Markham AF, Emery P, McGonagle D. Enumeration and phenotypic characterization of synovial fluid multipotential mesenchymal progenitor cells in inflammatory and degenerative arthritis. Arthritis Rheum 2004;50(3):817-27.

Jones EA, Crawford A, English A, Henshaw K, Mundy J, Corscadden D, Chapman T, Emery P, Hatton P, McGonagle D. Synovial fluid mesenchymal stem cells in health and early osteoarthritis: detection and functional evaluation at the single-cell level. Arthritis Rheum 2008;58(6):1731-40.

Koga H, Muneta T, Ju YJ, Nagase T, Nimura A, Mochizuki T, Ichinose S, von der Mark K, Sekiya I. Synovial stem cells are regionally specified according to local microenvironments after implantation for cartilage regeneration. Stem Cells 2007;25(3):689-96. 
Koyama N, Okubo Y, Nakao K, Bessho K. Evaluation of pluripotency in human dental pulp cells. J Oral Maxillofac Surg 2009;67(3):501-6.

Lendahl U, Zimmerman LB, McKay RD. CNS stem cells express a new class of intermediate filament protein. Cell 1990;60(4):585-95.

Luyten FP, Lories RJ, Verschueren P, de Vlam K, Westhovens R. Contemporary concepts of inflammation, damage and repair in rheumatic diseases. Best Pract Res Clin Rheumatol 2006;20(5):829-4.

Miura M, Gronthos S, Zhao M, Lu B, Fisher LW, Robey PG, Shi S. SHED: stem cells from human exfoliated deciduous teeth. Proc Natl Acad Sci U S A 2003;100(10):5807-12.

Miyamoto A, Deie M, Yamasaki T, Nakamae A, Shinomiya R, Adachi N, Ochi M. The role of the synovium in repairing cartilage defects. Knee Surg Sports Traumatol Arthrosc 2007;15(9):1083-93.

Mochizuki T, Muneta T, Sakaguchi Y, Nimura A, Yokoyama A, Koga H, Sekiya I. Higher chondrogenic potential of fibrous synovium- and adipose synovium-derived cells compared with subcutaneous fat-derived cells: distinguishing properties of 
mesenchymal stem cells in humans. Arthritis Rheum 2006;54(3):843-53.

Morito T, Muneta T, Hara K, Ju YJ, Mochizuki T, Makino H, Umezawa A, Sekiya I. Synovial fluid-derived mesenchymal stem cells increase after intra-articular ligament injury in humans. Rheumatology (Oxford) 2008;47(8):1137-43.

Mullen RJ, Buck CR, Smith AM. NeuN, a neuronal specific nuclear protein in vertebrates. Development 1992;116(1):201-11.

Nagase T, Muneta T, Ju YJ, Hara K, Morito T, Koga H, Nimura A, Mochizuki T, Sekiya I. Analysis of the chondrogenic potential of human synovial stem cells according to harvest site and culture parameters in knees with medial compartment osteoarthritis. Arthritis Rheum 2008;58(5):1389-98.

Neidel J, Schulze M, Sova L, Lindschau J. Practical significance of cytokine determination in joint fluid in patients with arthroses or rheumatoid arthritis. $\mathrm{Z}$ Orthop Ihre Grenzgeb. 1996;134(4):381-5.

Nishimura K, Solchaga LA, Caplan AI, Yoo JU, Goldberg VM, Johnstone B. Chondroprogenitor cells of synovial tissue. Arthritis Rheum 1999;42(12): 2631-37.

Okazaki R, Sakai A, Uezono Y, Ootsuyama A, Kunugita N, Nakamura T, Norimura T. Sequential changes in transforming growth factor (TGF)-beta1 concentration in 
synovial fluid and mRNA expression of TGF-betal receptors in chondrocytes after immobilization of rabbit knees. J Bone Miner Metab 2001;19(4):228-35.

Rodrigo JJ, Steadman JR, Syftestad G, Benton H, Silliman J. Effects of human knee synovial fluid on chondrogenesis in vitro. Am J Knee Surg 1995;8(4):124-9.

Sakaguchi Y, Sekiya I, Yagishita K, Muneta T. Comparison of human stem cells derived from various mesenchymal tissues. Arthritis Rheum 2005;52(8):2521-9.

Saris DB, Dhert WJ, Verbout AJ. Joint homeostasis. The discrepancy between old and fresh defects in cartilage repair. J Bone Joint Surg Br 2003;85(7):1067-76.

Sarnat HB, Nochlin D, Born DE. Neuronal nuclear antigen (NeuN): a marker of neuronal maturation in early human fetal nervous system. Brain Dev 1998;20(2):88-94.

Schmitt B, Ringe J, Häupl T, Notter M, Manz R, Burmester GR, Sittinger M, Kaps C. BMP2 initiates chondrogenic lineage development of adult human mesenchymal stem cells in high-density culture. Differentiation 2003;71(9):567-77.

Sekiya I, Larson BL, Vuoristo JT, Reger RL, Prockop DJ. Comparison of effect of BMP-2, -4 , and -6 on in vitro cartilage formation of human adult stem cells from bone marrow stroma. Cell Tissue Res 2005;320(2):269-76. 
Swann DA. Macromolecules of synovial fluid. In: L. Sokoloff (ed.), The Joints and Synovial Fluid. New York: Academic Press; 1978. p. 407-435. 
Figure legends

Figure 1. Characteristics of synovial fluid-derived adherent cells. (A) The typical morphology of synovial fluid-derived cells. The localized cells were negative for CD34 (B), a marker of hematopoietic progenitor cells, and CD45 (C), a marker of endothelial cells. The nuclei were counterstained with DAPI (B and C). (D) Synovial fluid-derived adherent cells showed STRO-1. Scale Bars: $100 \mu \mathrm{m}$.

Figure 2. Chondrogenic potential of synovial fluid-derived cells. (A) Levels of ALP activity of cell lysates on day 14 after treatment. (B) The results of toluidine blue staining on day 14. The cells were cultured in a micromass and treated with BMP-2. The cells were treated with BMP-2-induced toluidine blue-positive chondrocyte nodules. (C and D) The results of real-time RT-PCR on day $14 . \quad * P<0.05$. Gene expression levels were normalized with respect to endogenous $18 \mathrm{~S}$.

Figure 3. Osteogenic potential of synovial fluid-derived cells. The cells were cultured in osteogenic induction medium for 28 days. (A) The dishes were stained with von Kossa. Scale Bars: $100 \mu \mathrm{m}$. (B) Levels of ALP activity of cell lysates on day 28 after treatment. (C) The results of real-time RT-PCR on day 28. $* P<0.05$. Gene expression levels were normalized with respect to endogenous $18 \mathrm{~S}$. 
Figure 4. Adipogenic and neurogenic potential of synovial fluid-derived cells. The cells were cultured in adipogenic induction medium for 28 days. (A) The dishes were stained with oil red O. Cultures formed oil red o-positive lipid clusters after 28 days. Scale Bars: $100 \mu \mathrm{m}$. (C) The cells were cultured in neurogenic medium for 14 days. Differentiated cells expressed Nestin (D) and NeuN (E). Scale Bars: $100 \mu \mathrm{m}$. 


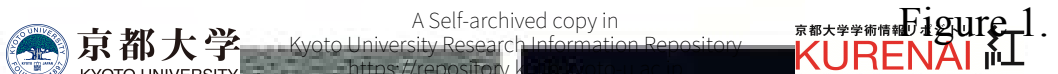

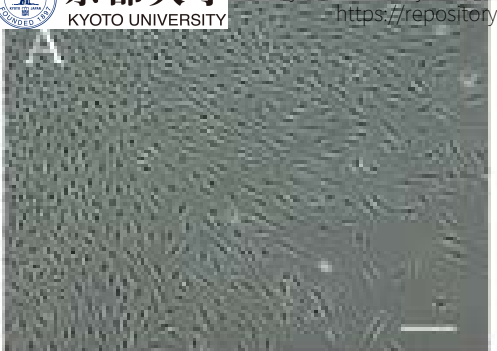
KURENAI iI Kyoto University Research Information Repository CD34

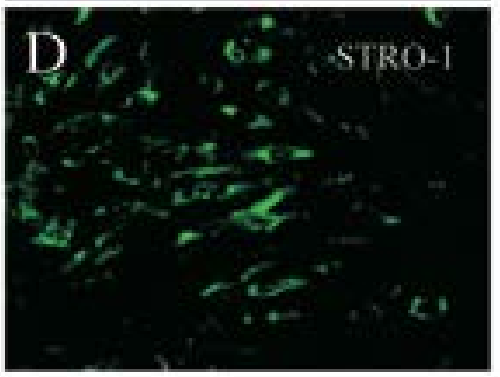


A Self-archived copy in

일 京都大学 KYOTO UNIVERSITY

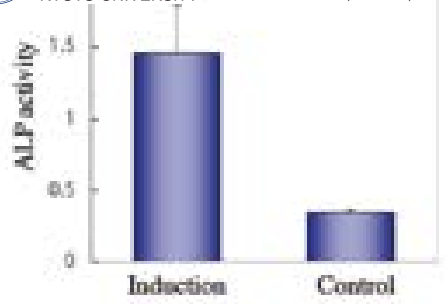

B

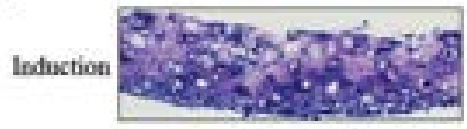

Coutrol

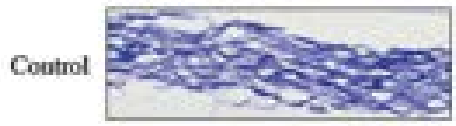

D
京都大学学術情辂り 林igure 2. KURENAI II

Kyoto University Research Information Repository
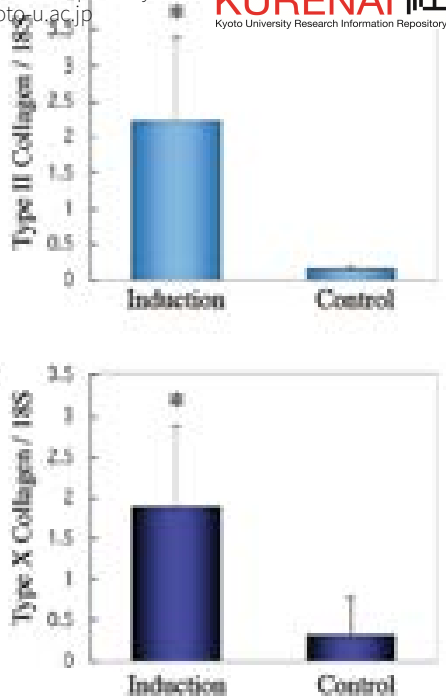
Eigure 3. кYOTO UNIVERSITY Rctibutips://repository.kulib.kyoto-u.ac.jp $\mathrm{C}_{\text {Kyoto University Research Information Repository }}$
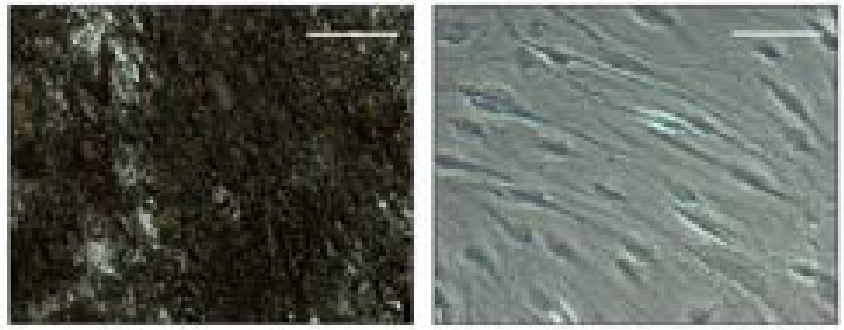

B

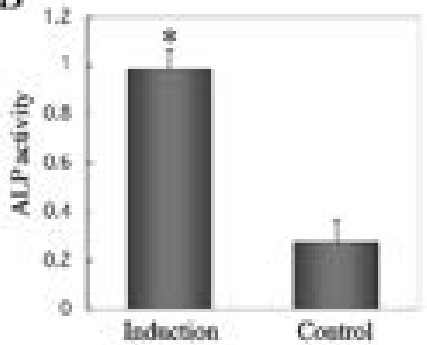

C

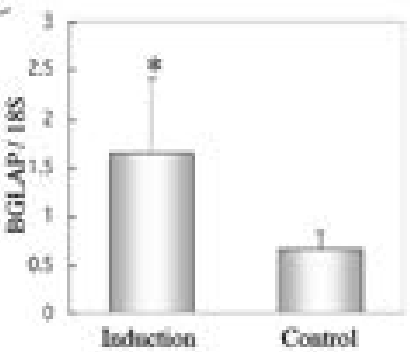




\section{KYOTOUNIVESITY}
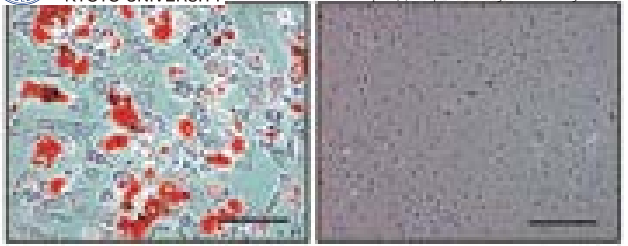
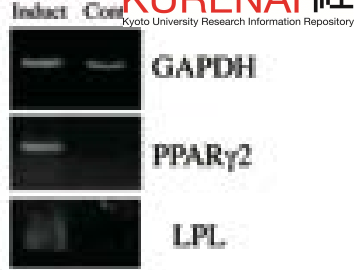

PPAR $\gamma 2$

LPL

C
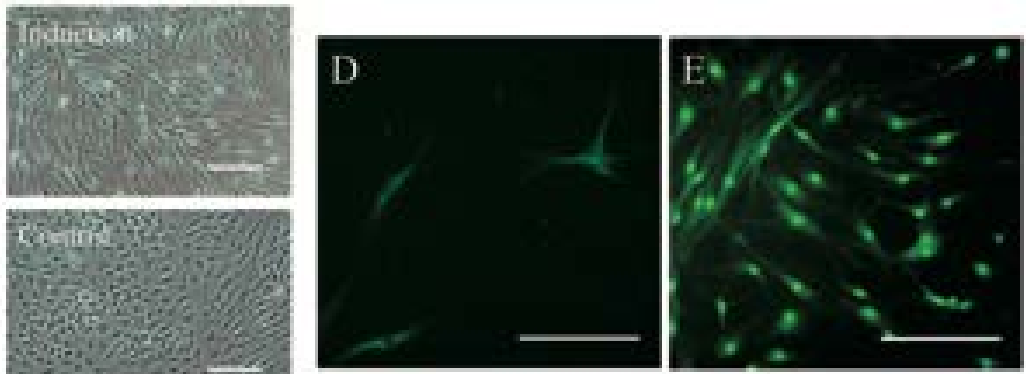